\title{
Polychlorinated Biphenyl (PCB) congener concentrations in aquatic birds. Case study: Ilha Grande Bay, Rio de Janeiro, Brazil
}

\author{
ALDO PACHECO FERREIRA \\ Escola Nacional de Saúde Pública Sérgio Arouca, FIOCRUZ, \\ Rua Leopoldo Bulhões, 1480, 21041-210 Rio de Janeiro, RJ, Brasil \\ Manuscript received on March 14, 2012; accepted for publication on November 1, 2012
}

\begin{abstract}
Livers from 108 birds found prostrate or dead in Ilha Grande Bay between 2005 and 2010 were analyzed for 16 PCB congeners (IUPAC numbers 8, 18, 28, 31, 52, 77, 101, 118, 126, 128, 138, 149, 153, 169, 170, and 180). The species analyzed were Egretta caerulea (Linnaeus 1758), Nycticorax nycticorax (Linnaeus 1758), Egretta thula (Molina 1782), and Ardea cocoi (Linnaeus 1766). The analysis were performed using Origin software $(7.5,2004)$ with a significant level of $p<0.05$. Data were checked for adherence to the standard assumptions of parametric tests using the Kolmogorov-Smirnov test for normality and the Levene's test for homogeneity of variances. This has revealed differences in concentration for some congeners. Results indicate relatively low PCBs contamination in aquatic birds, but it is implied the close relationship of environmental contamination, showing potential power of widespread biological and mutagenic adverse effects in trophic levels, and therefore, signalling risk to human health.
\end{abstract}

Key words: contamination, Ilha Grande Bay, polychlorinated biphenyl, risk to environment and health, aquatic birds.

\section{INTRODUCTION}

The pollution of aquatic systems is due not only to natural causes but above all to anthropogenic activity such as discharges of domestic or industrial effluents, leaching and runoff of pesticides in agricultural lands, among others (Morley 2010). Planar halogenated aromatic hydrocarbons such as non- and mono-ortho polychlorinated biphenyls (PCBs) have become known as biologically persistent, and extremely lipophilic environmental contaminants (Giesy et al. 1994, Breivik et al. 2002). These characteristics together with high lipophilicity $\left(\log \mathrm{K}_{\mathrm{ow}}\right.$ for PCBs from 4.9 to 8.2

Correspondence to: Aldo Pacheco Ferreira

E-mail: aldopachecoferreira@gmail.com
(Mackay et al. 1991) result in accumulation of PCBs in food web, as well as causing an ample assortment of toxic and biological effects such as reproductive failure, immune deficiency, teratogenesis, and irregular performance in animals and humans (Shaw et al. 2006).

Pollution in the marine environment has become an issue of great concern, especially to coastal states (Schmitt-Jansen et al. 2008). The oceans cannot provide an infinite sink for anthropogenic wastes but little attention has been given to evaluating the limits of capacity of coastal areas for waste assimilation (Carpenter 1998). Consequently, instances of fisheries closures, spoiled beaches, destroyed coral reefs and wildlife 
habitat, toxic blooms and lost coastal ecological communities are widespread; with a corresponding determination of cost benefit (Scheren et al. 2004).

Recent concerns about connectivity of ocean health issues and the relationship to human disease highlight an important area for study. Knowledge of the ocean and the impact of human activities on it can reveal the complexity and interdependence of all aspects of the system (Costanza and Farley 2007). Improved acquaintance and predictive capabilities are required for more effective and sustained development of the marine environment to obtain associated economic benefits and to preserve marine resources.

The aquatic environment with its water quality is considered the main factor controlling the state of health and disease in both man and animal. Nowadays, the increasing use of the waste chemical and agricultural drainage systems represents the most dangerous chemical pollution (Lacerda and Molisani 2006); and, their levels may be elevated as a result of increased input into the oceans resulting from industrial activities. In some cases the concentrations of certain chemicals in marine waters have reached levels which cause damage to wildlife populations and created serious human health problems. Identifying levels in wildlife which are elevated as a result of pollution is difficult, since very few data have been reported concerning the natural levels of PCBs in any species of marine vertebrates (Storelli et al. 2007).

Aquatic birds are conspicuous animals they are a suitable choice to play a role as sentinel organisms; unexpected changes in their numbers, health or breeding success provide an alarm that may indicate an unknown pollution or food supply problem (Lauwerys and Hoet 1993). Worldwide, seabird research has undergone a major evolution in terms of data collection, interpretation of the information and application in the field of management and policy (Tasker and Reid 1997). Aquatic birds are top consumers in marine food chains which offer opportunities to detect and assess the toxicological effects of different inorganic elements on the marine ecosystem (Walker et al. 2006). Consequently, studies assessing avian population status, reproductive success, and toxicological importance PCBs exposures can be extrapolated to other wildlife and probably humans (Ferreira 2008, Mallory et al. 2010).

Fish-eating birds may be well suited for the assessment of effects of PCBs due to their wide distribution (Basler 1994). They also bioaccumulate relatively high levels of PCBs due to their higher trophic levels and due to their limited abilities to metabolize anthropogenic compounds (Becher et al. 1995). To evaluate the ecotoxicological risks, toxic equivalency quantifications (TEQs) are constantly calculated with the World Health Organization (WHO) toxic equivalency factors (TEFs). Each congener of dioxins or dioxin-like PCBs exhibits a different level of toxicity. In order to be able to sum up the toxicity of these different congeners, the concept of TEFs has been introduced to facilitate risk assessment and regulatory control. This means that the analytical results relating to all the individual congeners or compounds of toxicological relevance are summed and expressed as TCDD toxic equivalent concentration or TEQ (Wania et al. 1998, Moriarty 1999).

The goal of this work was to evaluate concentrations of PCBs in livers of Egretta caerulea (Linnaeus 1758), Little Blue Heron, Nycticorax nycticorax (Linnaeus 1758), Black-crowned Night-heron, Egretta thula (Molina 1782), Snowy Egret, and Ardea cocoi (Linnaeus 1766) Coccoi Heron, collected from Ilha Grande Bay, which is situated in the southern Atlantic Coast of Rio de Janeiro State, Brazil.

\section{MATERIALS AND METHODS}

\section{STUDY SiTE}

Ilha Grande Bay is located in the southern state of Rio de Janeiro $\left(22^{\circ} 50^{\prime}-23^{\circ} 20^{\prime} \mathrm{S}, 44^{\circ} 00^{\prime}-44^{\circ}\right.$ 
$45^{\prime} \mathrm{W}$ ), and has an area of about 65.258 ha and $350 \mathrm{~km}$ perimeter on the waterline (Figure 1). The region has great scenic beauty a rich fauna and flora, and therefore a natural sanctuary for biodiversity (hot-spot), which lies between the two largest cities in South America - the cities of Rio de Janeiro and São Paulo. This richness and diversity of species, still little known, are due to geographic peculiarities, and hydrographic oceanographic region, coupled with factors such as diversity and connectivity of coastal systems, input of organic matter from rivers, physical variation and chemical oceanographic factors (Lailson-Brito et al. 2010).

The region of Ilha Grande Bay is home to the territories of the cities of Parati and Angra dos Reis, who had 145,000 inhabitants in 2010. In view of the beautiful landscape of the region, its main vocation naturally focuses on tourism and nautical leisure. Consequently, along the coast there is a green series of developments that, through the occupation of hillsides, riverbanks or islands and the landfill of mangrove areas, cause deforestation and polluted coastal waters. This growth as tourist hub promoted a disorderly development and causes severe damage to coastal systems. In the region there are still other large projects, such as a commercial port, a petroleum terminal, an ore terminal, two nuclear power plants and a shipyard (Ferreira 2010).

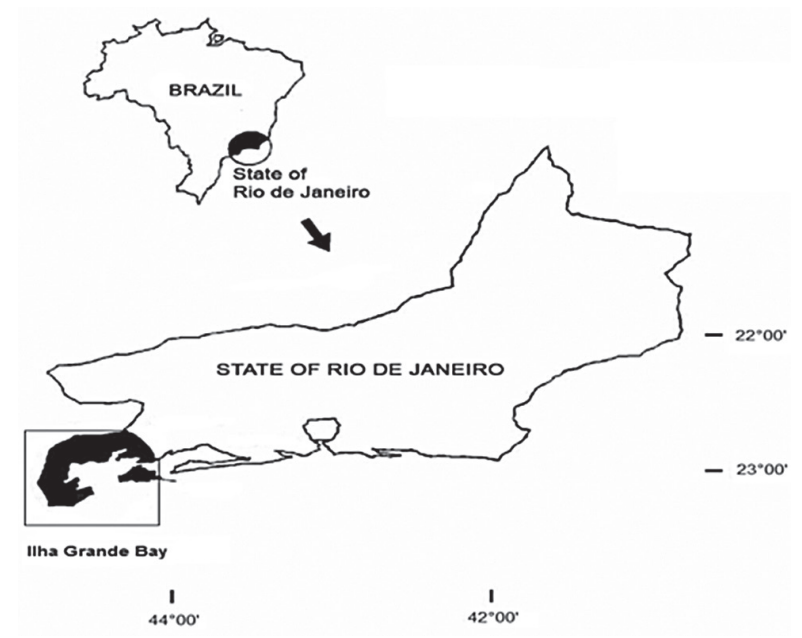

Figure 1 - Study area: Ilha Grande Bay, Rio de Janeiro, Brazil.

\section{ANALYTICAL PROCEDURES}

A total of 108 male aquatic birds (Egretta caerulea, $\mathrm{n}=21 ;$ Nycticorax nycticorax, $\mathrm{n}=25$; Egretta thula, $\mathrm{n}=35$; Ardea cocoi, $\mathrm{n}=27$ ) were collected as dead stranded animals from 2005 to 2010. All fresh carcasses were necropsied following a standardised protocol (Jauniaux et al. 1998). Livers were collected, weighed and kept frozen $\left(-18^{\circ} \mathrm{C}\right)$ prior to chemical analyses.

Chemical analysis of coplanar PCBs followed the method described in a previous report: USEPA Method 1668 (2003) and USEPA Method 8290 A (2007). Five grams of liver samples were weighed and lyophilised. Dry tissues were inserted in a steel extraction cell and placed in the Accelerated Solvent Extractor (ASE 200, Dionex). This machine using organic solvents operates under high pressure and temperature conditions $\left(10\right.$ minutes at $125^{\circ} \mathrm{C}$ and $1,500 \mathrm{psi}$ ) and allows the extraction of the different organic compounds present from the biological matrix. After being extracted, the samples were concentrated using Kuderna-Danish, the extract evaporated down to $1 \mathrm{~mL}$, and the solvent was transferred to $10 \mathrm{~mL}$ of $\mathrm{n}$-hexane. Fat content was determined gravimetrically from an aliquot of the extract (Kiviranta et al. 1999).

12 dioxin-like PCBs (IUPAC Nos. 81, 77, 126, $169,105,114,118,123,156,157,167$, and 189) were spiked. Furthermore, aliquots were treated with sulphuric acid (approximately 7-10 times) in a separation funnel. Then the hexane layer with PCBs was rinsed with hexane-washed water and dried by passing through anhydrous sodium sulphate in a glass funnel. The solution was concentrated to $2 \mathrm{~mL}$ and sequentially subjected to silica gel, alumina, and silica gel-impregnated activated carbon column chromatography. Extracts were passed through a silica gel-packed glass column (Wakogel, silica gel 60; 2 g) and eluted with 130 $\mathrm{mL}$ of hexane. The hexane extract was KudernaDanish concentrated and passed through alumina 
column (Merck-Alumina oxide, activity grade 1; 5 g) and eluted with $30 \mathrm{~mL}$ of $2 \%$ dichloromethane in hexane as a first fraction, which contained multi-ortho-substituted PCBs. The second fraction eluted with $30 \mathrm{~mL}$ of $50 \%$ dichloromethane in hexane, containing non- and mono-ortho-PCBs, was Kuderna-Danish concentrated and passed through silica gel-impregnated activated carbon column $(0.5 \mathrm{~g})$. The first fraction eluted with $25 \%$ dichloromethane in hexane contained mono- and di-ortho-PCBs.

Identification and quantification of dioxin-like PCBs (non- and mono-ortho-substituted congeners) was performed by use of a (i) Shimadzu GC-14B gas chromatograph with AOC-1400 auto-sampler. Columns: CBP-1 (SE-30) and CBP-5 (SE-52/54 confirmatory column). Injection: Splitless (30 s) $300^{\circ} \mathrm{C}$. Temperature program of the oven: $110 \mathrm{oC}(1$ $\min$.) $; 15^{\circ} \mathrm{C} / \mathrm{min}$ up $170^{\circ} \mathrm{C} ; 7.5^{\circ} \mathrm{C} / \mathrm{min}$ up to $290^{\circ} \mathrm{C}$, hold for 10 minutes. Total run time: 25 minutes. Electron Capture Detector $\left({ }^{63} \mathrm{Ni}\right)$ temperature: $310^{\circ}$ C; (ii) HPLC: Shimadzu LC-10AS; Mobile phase: acetonitrile: water $80 \%$, isocratic run. Column: Shimadzu STR-ODS-II (C-18 reverse phase) $25 \mathrm{~cm}$, L: 4mm ID. UV/VIS detector model: Shimadzu SPD-10A.

A procedural blank including extraction of blank Kimwipe and whole purification procedure was run with every batch (normally seven samples). The limit of quantification (LOQ) was set at 2 times the detected amount in the procedural blank. Reproducibility and recovery were confirmed through four replicate analyses of an abdominal adipose tissue sample with and without standard spiking. The relative standard deviations of concentrations of individual PCB-congeners were less than $5.8 \%$, and the recoveries were more than $96 \%$. The lipid contents were determined gravimetrically after aliquots of the sample extracts were evaporated to complete dryness.

The different congeners present in the sample were then analysed using a Gas Chromatography equipped with a capillary column of $40 \mu \mathrm{m}$ coupled to a High Resolution Mass Spectrometer (GCHRMS). They can be quantified and their concentration calculated when compared to the added internal $13^{\mathrm{C}}$ standard (Windal 2001). Results are expressed either as $\mathrm{pg} / \mathrm{g}$ of lipid mass or in terms of toxicity, using WHO TEF for birds (Van den Berg et al. 2006) as pg TEQ/g, lipid weight.

\section{CALCULATIONS}

The concentrations are expressed as geometric means ( $\mathrm{mg} / \mathrm{kg}$ wet weight) as suggested by Newton (1988) and Newton et al. (1993). The geometric mean removes the disportionate effects of outlying values and gives a value similar to the median but with greater potential for statistical evaluation (Kruuk and Conroy 1996). To calculate the geometric mean of each PCB congener to the total PCB concentration, all no detected values were treated as the value equivalent to half of the limit of detection. The total 2,3,7,8-TCDD toxic equivalent (TEQ) value for each sample was calculated using the toxic equivalency factors (TEFs) for birds recommended by the World Health Organization (Van den Berg et al. 2006). All statistical tests were performed using Origin software $(7.5,2004)$ with a significant level of $p<0.05$. Data were checked for adherence to the standard assumptions of parametric tests using the Kolmogorov-Smirnov test for normality and the Levene's test for homogeneity of variances.

\section{RESULTS}

The Table I presents the descriptive statistics of PCBs concentrations (pg/g lipid weight) in Egretta caerulea, Nycticorax nycticorax, Egretta thula and Ardea cocoi.

Concentrations of PCB-congeners with fat percentages are presented in Table II. Fat-based logtransformed concentrations were used to determine whether there were significant differences between group geometric means (Tukey test). Null hypothesis (equality of means) was rejected at the 
TABLE I

Descriptive statistics of PCBs concentrations (pg/g lipid weight) in aquatic birds.

\begin{tabular}{ccccccccccccc}
\hline \multirow{2}{*}{$\begin{array}{c}\text { Aquatic } \\
\text { bird }\end{array}$} & Mean & sd(yEr \pm ) & se(yEr \pm ) & P25 & P75 & P95 & Min & Max & Range & Median & Var & Coef Var \\
\cline { 2 - 12 } \\
\hline $\begin{array}{c}\text { Egretta } \\
\text { caerulea }\end{array}$ & 85.08333 & 73.11567 & 21.10668 & 17 & 132 & 228 & 12 & 228 & 216 & 68.5 & $5,345.90152$ & 0.85934 \\
\hline $\begin{array}{c}\text { Nycticorax } \\
\text { nycticorax }\end{array}$ & 63.75 & 53.30892 & 15.38896 & 19 & 98 & 166 & 12 & 166 & 154 & 46 & $2,841.84091$ & 0.83622 \\
\hline $\begin{array}{c}\text { Egretta } \\
\text { thula }\end{array}$ & 129.66667 & 97.75975 & 28.22081 & 43 & 211 & 298 & 37 & 298 & 261 & 88.5 & $9,556.9697$ & 0.75393 \\
\hline Ardea cocoi & 54.5 & 46.51197 & 13.42685 & 16 & 65 & 147 & 9 & 147 & 138 & 39.5 & $2,163.36364$ & 0.85343 \\
\hline
\end{tabular}

Mean. Sd $=$ Standard deviation of data. Se $=$ Standard error of the mean. P25 = 25 percentile. P75 $=75$ percentile. P95 $=95$ percentile. Min= Minimum. Max= Maximun. Range. Median. Var $=$ Variance. Coef Var $=$ Coefficient of variation.

95\% significance level $(\mathrm{p}<0.05)$. The medians of concentrations of PCBs (pg/g lipid weight) and toxic equivalents of $\mathrm{PCBs}$ (pg TEQ/g lipid weight) presented expressed no significant species-related differences in PCB. There were no statistically significant differences between mean PCBcongeners concentrations between the species.

Data in figure 2 shows the distribution of PCB congeners. PCB 105 congener accounted for $22.33 \%$ of $\Sigma$ PCB in Egretta caerulea, $22.05 \%$ of $\Sigma \mathrm{PCB}$ in Egretta thula, and $22.47 \%$ of $\Sigma \mathrm{PCB}$ in Ardea coccoi. PCB 114 congener accounted for $21.70 \%$ of $\Sigma \mathrm{PCB}$ in Nycticorax nycticorax.

TEQs of PCBs were calculated using TEFs for birds proposed byWHO (Van der Berg et al. 2006), and compositions are shown in figure 3.

\section{DISCUSSION}

Increased human activities such as industrialization, coupled with over-population and increased ambient temperature amongst other factors, have become major environmental issues in recent years. As a result of such actions, additional studies which include the environment and their indicators are important because they can show potential impacts that are being reflected, and extending to public health. Thus, the study of ecotoxicology is a very broad field of science where issues such as uptake and effects in organisms, as well as distribution and residence time of the pollutants in the trophic level are studied in many different ways.

The fundamental question to answer is whether the trophic level is harmfully disturbed when polluted by toxicants. To answer this important question, quantitative understanding of the pollutants behaviour within ecosystems is essential, and therefore researchers develop methods to manage this. The presence of anthropogenic pollutants, such as PCB-congeners, throughout all compartments of the marine environment has been of international concern for a number of decades (Kumar et al. 2001). While a great number of datasets documenting absolute concentrations of persistent organic pollutants in a variety of marine biota are available, the bioaccumulative nature, toxicity, biomagnification, and the fate of these compounds in the marine ecosystem is still poorly understood (Pereira 2004). Data on contaminant levels in Brazilian aquatic birds are limited, and no information exists regarding levels of new or emerging contaminants.

The PCB congeners detected at the highest concentrations were 105 and 114 . The congener profile determined in these birds probably reflects differences in both exposures to PCB congeners and in ability to metabolize them. 
TABLE II

Medians (range) of concentrations as pg/g lipid weight of PCBs and toxic equivalents of PCBs (pg TEQ/g lipid weight) in Egretta caerulea, Nycticorax nycticorax, Egretta thula, and Ardea cocoi.

\begin{tabular}{|c|c|c|c|c|c|c|c|c|}
\hline \multirow[b]{2}{*}{ Elements } & \multicolumn{2}{|c|}{ Egretta caerulea } & \multicolumn{2}{|c|}{ Nycticorax nycticorax } & \multicolumn{2}{|c|}{ Egretta thula } & \multicolumn{2}{|c|}{ Ardea cocoi } \\
\hline & Concentration & $\begin{array}{c}\text { WHO } \\
\text { TEF } \\
\text { (birds) }\end{array}$ & Concentration & $\begin{array}{c}\text { WHO } \\
\text { TEF } \\
\text { (birds) }\end{array}$ & Concentration & $\begin{array}{c}\text { WHO } \\
\text { TEF } \\
\text { (birds) }\end{array}$ & Concentration & $\begin{array}{c}\text { WHO } \\
\text { TEF } \\
\text { (birds) }\end{array}$ \\
\hline \multicolumn{9}{|l|}{ Non-ortho PCBs } \\
\hline $\begin{array}{l}3,3^{\prime}, 4,4^{\prime}- \\
\text { TCB (77) }\end{array}$ & $132(67-445)$ & 6.6 & $98(44-222)$ & 4.9 & $211(52-354)$ & 10.55 & $65(30-291)$ & 3.25 \\
\hline $\begin{array}{c}3,4,4,5- \\
\text { TCB }(81)\end{array}$ & $54(23-466)$ & 5.4 & $37(14-152)$ & 3.78 & $71(26-455)$ & 7.1 & $48(22-366)$ & 4.8 \\
\hline $\begin{array}{c}3,3^{\prime}, 4,4^{\prime}, 5- \\
\text { PeCB (126) }\end{array}$ & $79(44-192)$ & 7.9 & $55(31-168)$ & 5.5 & $93(32-228)$ & 9.3 & $33(16-102)$ & 3.3 \\
\hline $\begin{array}{l}3,3^{\prime}, 4,4^{\prime}, 5,5^{\prime}- \\
\mathrm{HxCB}(169)\end{array}$ & $77(35-221)$ & 0.077 & $26(11-63)$ & 0.026 & $84(31-167)$ & 0.084 & $35(19-123)$ & 0.035 \\
\hline \multicolumn{9}{|c|}{ Mono-ortho PCBs } \\
\hline $\begin{array}{c}2,3,3^{\prime}, 4,4^{\prime}- \\
\text { PeCB (105) }\end{array}$ & $228(62-355)$ & 0.0228 & $149(34-296)$ & 0.0149 & $298(81-404)$ & 0.0298 & $147(26-210)$ & 0.0147 \\
\hline $\begin{array}{c}2,3,4,4 ', 5- \\
\text { PeCB (114) }\end{array}$ & $198(52-311)$ & 0.0198 & $166(64-259)$ & 0.0166 & $278(44-386)$ & 0.0278 & $133(35-222)$ & 0.0133 \\
\hline $\begin{array}{c}2,3^{\prime}, 4,4^{\prime}, 5- \\
\text { PeCB (118) }\end{array}$ & $132(45-266)$ & 0.00132 & $102(32-218)$ & 0.00102 & $235(40-339)$ & 0.00235 & $92(31-266)$ & 0.00092 \\
\hline $\begin{array}{c}2^{\prime}, 3,4,4^{\prime}, 5- \\
\text { PeCB (123) }\end{array}$ & $60(28-148)$ & 0.0006 & $62(19-127)$ & 0.00062 & $112(56-264)$ & 0.00112 & $44(20-136)$ & 0.00044 \\
\hline $\begin{array}{l}2,3,3^{\prime}, 4,4^{\prime}, 5- \\
\mathrm{HxCB}(156)\end{array}$ & $14(9-52)$ & 0.0014 & $13(7-87)$ & 0.0013 & $39(15-122)$ & 0.0039 & $11(7-56)$ & 0.0011 \\
\hline $\begin{array}{l}2,3,3^{\prime}, 4,4^{\prime}, 5^{\prime}- \\
\mathrm{HxCB}(157)\end{array}$ & $12(8-43)$ & 0.0012 & $19(7-77)$ & 0.0019 & $37(11-89)$ & 0.0037 & $9(4-32)$ & 0.0009 \\
\hline $\begin{array}{l}2,3^{\prime}, 4,4^{\prime}, 5,5^{\prime}- \\
\mathrm{HxCB}(167)\end{array}$ & $18(11-59)$ & 0.00018 & $26(10-72)$ & 0.00026 & $55(29-111)$ & 0.00055 & $16(7-68)$ & 0.00016 \\
\hline \multirow[t]{2}{*}{$\begin{array}{c}2,3,3^{\prime}, 4,4^{\prime}, 5,5^{\prime}- \\
\text { HeCB (189) }\end{array}$} & $17(9-38)$ & 0.00017 & $12(6-34)$ & 0.00012 & $43(16-101)$ & 0.00043 & $21(14-62)$ & 0.00021 \\
\hline & $\Sigma=1,021$ & $\Sigma=20.02$ & $\Sigma=765$ & $\Sigma=14.24$ & $\Sigma=1,351$ & $\Sigma=27.10$ & $\Sigma=654$ & $\Sigma=11.41$ \\
\hline
\end{tabular}

Lailson-Brito et al. (2010) studying organochlorine accumulation in Guiana dolphin (Sotalia guianensis), at the same study site found concentrations levels from 0.765 to $99.175 \mathrm{pg} / \mathrm{g}$ lipid for $\Sigma \mathrm{PCB}$. Some oceanic islands, such as São Pedro e São Paulo Archipelago, is a group of small rocky islands that lies in the central equatorial Atlantic Ocean, lying $627 \mathrm{~km}$ from the archipelago of Fernando de Noronha, $986 \mathrm{~km}$ from the nearest point on the mainland and 1,010 km from Natal, in Rio Grande do Norte, Brazil; may be considered remote areas and preserved due to its distance from the mainland. However, these areas are not exempt from the influence of anthropogenic agents from coastal regions, such as persistent organic pollutants (POPs). The predominant compounds were PCBs that presented $98.15 \mathrm{ng} / \mathrm{g}$ to Sula leucogaster (Brown Booby) (Dias 2010). The low levels of contaminants suggest a relative degree of isolation and preservation, but the occurrence and distribution profiles of PCBs supports the hypothesis that the main source of contamination in remote areas is long range atmospheric transport, and demonstrates the ubiquity of those pollutants 


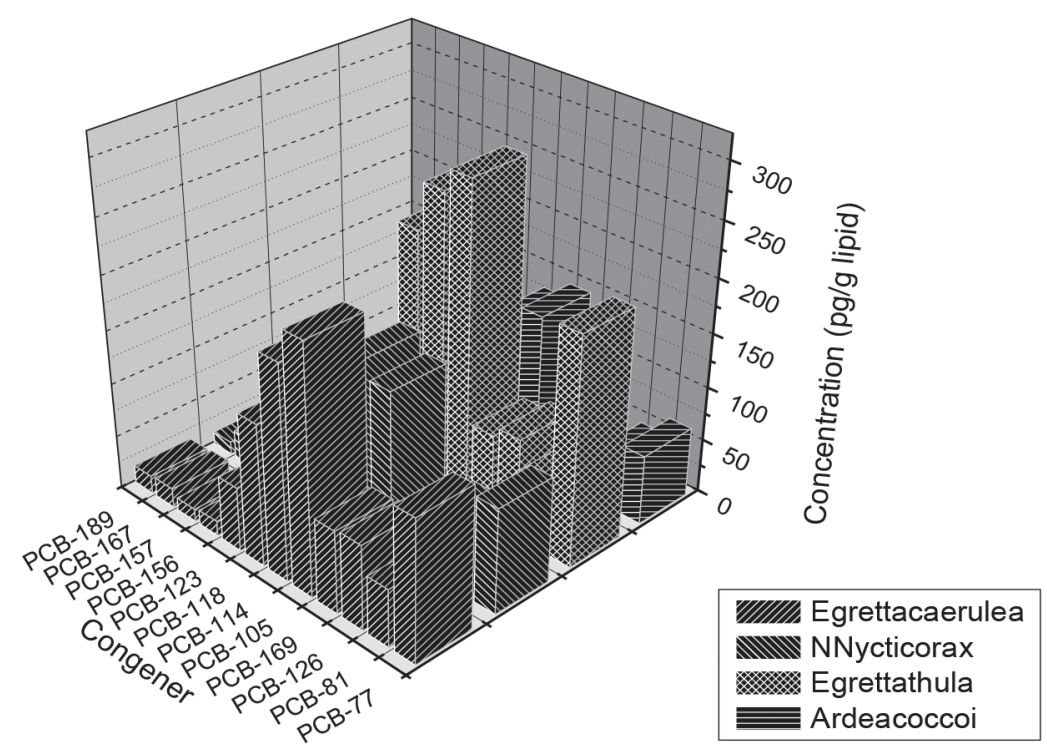

Figure 2 - Concentrations of PCB Congeners in avian species studied (pg/g lipid).

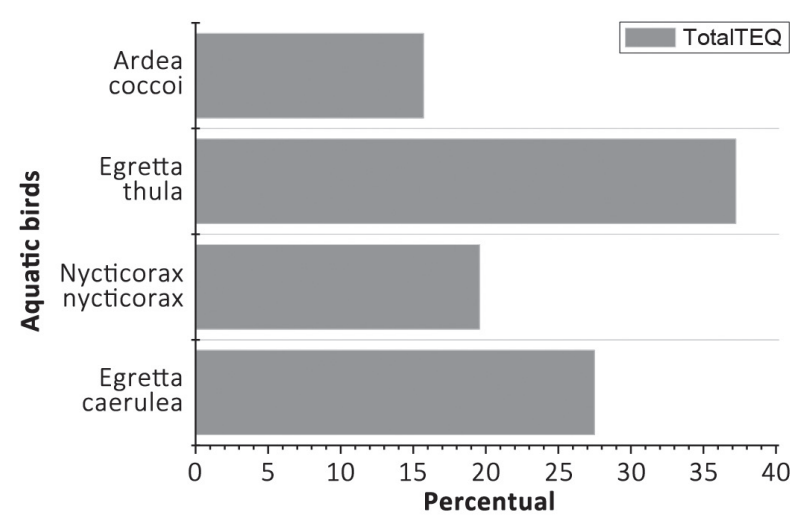

Figure 3 - Contributions of dioxin-like PCBs to Total TEQ.

in the marine environment. Cunha et al. (2012) studying dichlorodiphenyltrichloroethane (DDT) and polychlorinated biphenyls (PCBs), in the eggs of the Brown Booby (Sula leucogaster) collected from breeding colonies located on three archipelagos (Saint Peter and Saint Paul, Abrolhos and Cagarras Islands) in the Atlantic Ocean, found concentrations levels of $0.05 \mu \mathrm{g} \cdot \mathrm{g}^{-1}$ of $\sum \mathrm{PCBs}$ and $0.01 \mu \mathrm{g} . \mathrm{g}^{-1}$ of $\sum \mathrm{DDT}, 0.19 \mu \mathrm{g} . \mathrm{g}^{-1}$ of $\sum$ PCBs and $0.03 \mu \mathrm{g} . \mathrm{g}^{-1}$ of $\sum \mathrm{DDT}$, and $8.4 \mu \mathrm{g} . \mathrm{g}^{-1}$ of $\sum \mathrm{PCBs}$ and $1.8 \mu \mathrm{g}^{\mathrm{g}} \mathrm{g}^{-1}$ of $\sum \mathrm{DDT}$, respectively. The total PCB level is close to the threshold values considered to be harmful to birds. The findings indicate that the brown booby colony closest to the Rio de Janeiro coast has recently been exposed to DDT. Despite the high pollution levels found on the Cagarras Islands, no alterations in the eggshell weight or the thickness of the analyzed eggs were detected.

The toxicity of individual congeners was assessed using the toxic equivalency approach (Van den Berg et al. 2006). There is a paucity of TEF values reported for seabird livers (Guruge et al. 2000, Choi et al. 2001, Kumar et al. 2002). However, care must be taken when comparing total TEQ values as other studies may include TEQ values from additional contaminants including chlorinated dibenzo-p-dioxins, furans, and chloronaphthalenes, giving TEQ values potentially greater than those reported here. However TEQ values based solely on PCBs are still of some use, as PCBs accounted for $60 \%$ to $85 \%$ of the total TEQ concentrations reported in bird livers analyzed for all contaminant groups (Kannan et al. 2002).

In previous studies, the monitoring of POPs in aquatic birds has been limited by the availability in organs (Peakall et al. 1990, Shaffer et al. 2006). This approach can easily be combined with ecological investigations of aquatic birds, and so 
this could dramatically increase the availability of seabird samples, including repeated sampling on identical birds (Holmström and Berger 2008). Recently, electronic tracking tags have revolutionized our understanding of the largescale movements and habitat use of mobile marine animals (Shaffer et al. 2006).

Reported adverse effects of POPs in wildlife include population declines, increases in cancers, reduced reproductive function, disrupted development of immune and nervous systems, and also elicit toxic responses which could result in the disruption of the endocrine system (Alcock et al. 1998, Rittler and Castilla 2002). The assessment of environmental variables and biological effects in aquatic birds will provide critical insights into the level and extent in public health effects associated with marine areas and resources. Additively, these chemicals may produce a significant effect. In part, the lack of evidence reflects the fact that relatively little research has been done. Also, the direct contaminant loads and exposure will assist regional, and consequently, national decision makers in efforts to ensure the sustained protection to marine ecosystems.

\section{CONCLUSION}

The presence of tissue levels of PCBs can be associated with biological and physiological effects in marine organisms, in especially aquatic birds (Montevecchi 1993, Holmström and Berger 2008). The animals sampled in the current study had PCB congeners yet in low values, but in a more expressive than other studies here mentioned. As production of PCBs and their use systematically declined greatly since the late 1960s and early 1970s, it might be expected that current concentrations in comparable biological compartments (e.g., seabird livers) could be lower; but still presents occasionally high. However, this study shows that such a simplistic view is not valid. Indeed, there were large intra- and interspecies differences in total PCB concentrations found in these birds. This suggests that the intra- and interspecies differences were at least partly due to characteristics of the locations in which the birds feed and live. The findings for the individual congeners were similar to the findings for total PCBs, although conclusions for some of the congeners are less clear due to differences in the relative proportion of congeners found in the birds. Factors that might affect the concentration of chemicals in seabird livers residues of any contaminant measured in a bird will vary according to many factors, including exposure to the chemical, metabolic capabilities, and the nutritional state of the bird.

The current study is still the first to report aquatic birds' concentrations of POPs at this study site, and the first for any free-ranging birds from the Ilha Grande Bay. And continued monitoring of POPs is essential in assessing the health and viability of these animals. The present study confirms the ubiquity of POPs in species studied, belonging the marine environment of Ilha Grande Bay, Rio de janeiro, Brazil. Biomagnifications may be the cause of the levels in the species collected and analysed. Further assessments are recommended on organisms at higher trophic levels for ecotoxicological impacts. The ubiquity of these pollutants in Ilha Grande Bay's marine environment supports the need for a greater awareness of bioaccumulation processes, particularly for organisms cultivated (shellfish) or fished locally and destined for human consumption.

\section{ACKNOWLEDGMENTS}

The author is grateful for financial support received from the Conselho Nacional de Desenvolvimento Científico e Tecnológico (CNPq) (302946/2011-0).

\section{RESUMO}

Fígados de 108 pássaros encontrados prostrados ou mortos na Baía da Ilha Grande entre 2005 e 2010 foram analisados para 16 congêneres de PCB (IUPAC 
números $8,18,28,31,52,77,101,118,126,128,138$, $149,153,169,170$ e 180). As espécies analisadas foram Egretta caerulea (Linnaeus 1758), Nycticorax nycticorax (Linnaeus 1758), Egretta thula (Molina 1782) e Ardea cocoi (Linnaeus 1766). As análises foram realizadas utilizando o software Origin $(7.5,2004)$ com um nível significativo de $p<0,05$. Os dados foram checados para a adesão aos pressupostos padrão dos testes paramétricos, utilizando o teste Kolmogorov-Smirnov para normalidade e teste de Levene para homogeneidade das variâncias. Isto revelou diferenças na concentração de alguns congêneres. Os resultados indicam relativamente baixa contaminação PCBs em aves marinhas, mas está implícita a estreita relação de contaminação ambiental, evidenciando potencial poder de generalização adversa de efeitos biológicos e mutagênicos em níveis tróficos e, por conseguinte, sinalizando risco para a saúde humana.

Palavras-chave: contaminação, Baía da Ilha Grande, bifenilas policloradas, risco ao ambiente e saúde, aves marinhas.

\section{REFERENCES}

Alcock RE, Behnisch PA, Jones KC AND HagenMaIer H. 1998. Dioxin-Like PCBS in the environment. Human exposure and the significance of sources. Chemosphere 37: 1457-1472.

BASLER A. 1994. Regulatory measures in the Federal Republic of Germany to reduce the exposure of man and the environment to dioxins. Organohalogen Compd 20: 567570.

Becher G, Skatre JU, Polder A, Sletten B, Rossland OJ AND HANSEN HK. 1995. PCDDS, PCDFS, and PCBS in human milk from different parts of Norway and Lithuania. J Toxicol Environ Health 46: 133-148.

Breivik K, SweEtman A, PaCyna JM AND Jones KC. 2002. Towards a global historical emission inventory for selected PCB congeners - a mass balance approach 2 . Global production and consumption. Sci Total Environ 290: 181-198.

CARPENTER DO. 1998. Polychlorinated Biphenyls and Human Health. Int J Occup Med Environ Health 11: 291-303.

CHOI JW, MATSUDAM, KAWANO M, Min BY AND WAKIMOTO T. 2001. Accumulation profiles of persistent organochlorines in waterbirds from an estuary in Korea. Arch Environ Contam Toxicol 41: 353-363.

Costanza R AND FARLEy J. 2007. Ecological economics of coastal disasters: Introduction to the special issue. Ecology \& Economics 63(2-3): 249-253.
CUNHA LST, TORRES JPM, MUÑOZ-ARNANZ J AND JIMÉNEZ B. 2012. Evaluation of the possible adverse effects of legacy persistent organic pollutants (POPs) on the brown booby (Sula leucogaster) along the Brazilian coast. Chemosphere 87: 1039-1044.

DIAS OS. 2010. Poluentes orgânicos persistentes na biota marinha do arquipélago de São Pedro e São Paulo. Dissertação de Mestrado. Instituto Oceanográfico. Universidade de São Paulo, 79 p.

FERREIRA AP. 2008. Environmental fate of bioaccumulative and persistent substances. A synopsis of existing and future actions. Gerencia y Politicas de Salud 7(15): 14-23.

FERreirA AP. 2010. Trace metals analysis in Brown Booby (Sula Leocogaster) collected from Ilha Grande Bay, Rio de Janeiro, Brazil. Uniandrade 11(2): 41-53.

Giesy JP, Ludwig JP AND TILlitT DE. 1994. Dioxins, Dibenzofurans, Pcbs and colonial, fish-eating water birds. In: Schecter A(Ed), Dioxins and Health. Plenum Publishers, New York, NY, 307 p.

Guruge KS, TANABE S AND FuKuda M. 2000. TOXIC ASSEssment of PCBs by the 2,3,7,8-tetrachlorodibenzo-pdioxin equivalent in common cormorant (Phalacrocorax carbo) from Japan. Arch Environ Contam Toxicol 38: 509-521.

HOLMSTRÖM K AND BERGER U. 2008. Tissue distribution of perfluorinated surfactants in common Guillemot (Uria Aalge) from the Baltic sea. Environ Sci Technol 42: 5879-5884.

JauniauX T, Brosens L, MeIre P, OfFringa Hand CoIGNOUL F. 1998. Pathological investigations on guillemots (Uria aalge) stranded on the Belgian coast during the winter of 1993-94. The Veterinary Record 143(14): 387-390.

KANNAN K, CORSOLINI S, IMAGAWA T, FOCARDI S AND GIESY JP. 2002. Polychlorinated -naphthalenes, -biphenyls, -dibenzo-p-dioxins, dibenzofurans and p,p_-DDE in bluefin tuna, swordfish, cormorants and barn swallows from Italy. Ambio 31: 207-211.

KiviRANTA H, PURKUNEN R AND VARTIAINEN T. 1999. Levels and trends of PCDD/FS and PCBS in human milk in Finland. Chemosphere 38(2): 311-323.

KRUUK H AND CONROY JWH. 1996. Concentrations of some organochlorines in otters (Lutra lutra L.) in Scotland: implications for populations. Environ Pollut 92: 165-171.

Kumar KS, KanNan K, CORSOlini S, Evans T, GIESY JP, NAKANISHI J AND MASUNAGA S. 2002. Polychlorinated dibenzo-p-dioxins, dibenzo- furans and polychlorinated biphenyls in polar bear, penguin and south polar skua. Environ Pollut 119: 151-161.

Kumar KS, KanNAN K, PARAMasivan ON, SUndaram VPS, NAKANISHI J AND MASUnAGA S. 2001. Polychlorinated Dibenzo-p-Dioxins, Dibenzofurans, and Polychlorinated Biphenyls in human tissues, meat, fish, and wildlife samples from India. Environ Sci Technol 35(17): 3448-3455.

LACERDA LD AND Molisani MM. 2006. Three decades of Cd and $\mathrm{Zn}$ contamination in Sepetiba Bay, SE Brazil: Evidence from the mangrove oyster Crassostraea rhizophorae. Mar Pollut Bull 52(8): 974-977. 
LAILSON-BRITO J ET AL. 2010. High organochlorine accumulation in blubber of guiana dolphin, Sotalia Guianensis, from Brazilian coast and its use to establish geographical differences among populations. Environ Pollut 158(5): 1800-1808.

LAUWERYS R AND HoET P. 1993. Industrial Chemical Exposure. Guidelines for biological monitoring. Lewis Publishers: Boca Raton, 199 p.

MACKAY D, SHIU WY AND MA KC. 1991. Illustrated handbook of physical-chemical properties and environmental fate for organic chemicals. Volume I. Monoaromatic Hydrocarbons, Chlorobenzenes and PCBS. Lewis Publishers, Boca Raton, FL, 697 p.

Mallory ML, Robinson SA, Hebert CE AND Forbes MR. 2010. Aquatic birds as indicators of aquatic ecosystem conditions: A case for gathering multiple proxies of seabird health. Mar Pollut Bull 60(1): 7-12.

MoNTEVECCHI WA. 1993. Birds as indicators of change in marine prey stocks. In: Furness RW and Greenwood JJD (Eds), Birds as monitors of environmental change. Chapman \& Hall, London, 223 p.

MoriarTy F. 1999. Ecotoxicology. The study of polluants in ecosistems. $3^{\text {rd }}$ Edition, Academic Press, California, USA, $109 \mathrm{p}$.

MorLey NJ. 2010. Interactive effects of infectious diseases and pollution in aquatic molluscs. Aquat Toxicol 96(1): 27-36.

NEWTON I. 1988. Determination of critical pollutant levels in wild populations, with examples from organochlorine insecticides in birds of prey. Environ Pollut 55: 29-40.

NEWTON I, WyLlie I AND ASHER A. 1993. Long-term trends in organochlorine and mercury residues in some predatory birds in Britain. Environ Pollut 79: 143-151.

Peakall DB, Noble DG, Elliott JE, Somers JD AND ERICKSON G. 1990. Environmental Contaminants in Canadian peregrine falcons, Falco Peregrinus: A toxicological assessment. Can Field Naturalist 104: 244-254.

PEREIRA MS. 2004. Polychlorinated Dibenzo-p-Dioxins (PCDD), Dibenzofurans (PCDF) and Polychlorinated Biphenyls (PCB): Main sources, environmental behaviour and risk to man and biota. Quím Nova 27(6): 934-943.

RITTLER M AND CASTILLA EE. 2002. Desreguladores endócrinos e anomalias congênitas. Cad Saúde Públ 18(2): 421-428.

SCheren PAGM, Kroeze C, JANSSEN FJJG, HordiJK L AND PTASINSKI KJ. 2004. Integrated water pollution assessment of the Ebrié Lagoon, Ivory Coast, West Africa. J Mar Systems 44(1-2): 1-17.
SChmitt-Jansen M, Veit U, Dudel G AND Altenburger R 2008. An ecological perspective in aquatic ecotoxicology: Approaches and challenges. Basic and Applied Ecology 9(4): 337-345.

ShafFer SA, Tremblay Y, WeIMERSKIRCH H, SCOTt D, THOMPSON DR, SAGAR PM, MOLlER H, TAYLOR GA, Foley DG, BLOCK BA AND CosTA DP. 2006. Migratory shearwaters integrate oceanic resources across the Pacific ocean in an endless summer. Proc Nat Acad Sci USA 103: 12799-12802.

ShaW SD, Berger ML, BrenNer D, ChU MD, MATHERly CK, Chu AC and Clark GC. 2006. Application of the calux bioassay for the determination of $\mathrm{PCDD} / \mathrm{FS}$ and dioxinlike PCBS in tissues of harbor seals. Organohalogen Compds 68: 587-591.

Storelli MM, Perrone VG AND MARCotrigiano GO. 2007. Organochlorine contamination (PCBs and DDTs) in deepsea fish from the Mediterranean sea. Mar Pollut Bull 54(12): 1968-1971.

TASKER ML AND REID JB. 1997. Aquatic birds in the marine environment: Introduction. Ices J Mar Sci 54: 505-506.

USEPA - UNITED STATES ENVIRONMENTAL PROTECTION AGENCY. 2003. Method 1668: Revision A. Chlorinated Biphenyl congeners in water, soil, sediment, biosolids, and tissue by HRGC/HRMS.

USEPA - United States EnVironmental Protection AGENCY. 2007. Method 8290 A: Revision 1. Polychlorinated Dibenzodioxins (PCDDS) and Polychlorinated Dibenzofurans (PCDFS) by high-resolution gas chromatography/ high-resolution mass spectrometry (HRGC/HRMS).

VAN DEN BERG M, BIRNBAum LS AND DENISON M. 2006. The 2005 World Health Organization re-evaluation of human and mammalian toxic equivalency factors for dioxins and dioxin-like compounds. Toxicol Sci 93(2): 223-241.

WALKer CH, Hopkin SP, Sibly RM AND PEAKALL DB. 2006. Principles of Ecotoxicology. Third Edition, CRC Press, USA, $386 \mathrm{p}$.

WANIA F, AXELMAN J AND BROMAN D. 1998. A review of processes involved in the exchange of persistent organic pollutants across the air-sea interface. Environ Pollut 102: 3-23.

Windal I. 2001. Développement de méthodes rapides d'analyse des dioxines dans lês poussières d'incinérateurs et destruction des dioxines par eaux subcritique. Thesis, University of Liège, $135 \mathrm{p}$. 